Check for updates

The BMJ

Cite this as: BMJ 2021;374:n1963 http://dx.doi.org/10.1136/bmj.n1963 Published: 06 August 2021

\title{
Covid-19: Junior doctors write to young people to acknowledge vaccine concerns
}

\section{Gareth lacobucci}

A group of junior doctors from Scotland have written to young people in their age group to try to ease concerns they may have about receiving the covid-19 vaccine.

In an open letter sent on Friday 6 August the doctors, all in their 20 and 30s, acknowledged the pandemic's effects on the lives of young people and that some were reluctant to be vaccinated. ${ }^{1}$

"Young people have had to put parts of their lives on hold-which is frustrating. Sometimes it feels like we are just being left out. As young medics, we share that frustration. We want to get our lives back to normal as quickly as possible too," they wrote.

They recognised that young people might be fed up with being told what to do by government officials and mistrust what they say. "Although politicians do most of the talking about vaccines, we're mindful that it was scientists who did the research. Many stopped working on their own research projects, to join huge teams working on the covid-19 vaccines. Their efforts led to safe and effective vaccines in record time. It's terrible to think where we would all be if that hadn't happened," said the letter.

It also acknowledged that some young people, including pregnant women, were worried about possible side effects of vaccination. "There's a lot of misinformation on social media at the moment and that leads to mistrust," it said. "But side effects are normally very mild-symptoms like a sore head, a sore arm, or tiredness normally last for just a couple of days. That's better than the symptoms of covid-19 itself, or long covid-which can go on for months and be much worse.

"About one in 10 pregnant women admitted to hospital with symptoms of covid-19 requires intensive care, and about one in five gives birth prematurely, according to new data published by the University of Oxford. Vaccination from covid-19 will protect you and your baby."

The letter highlighted the high numbers of hospital admissions among people in their 20 and 30 s who had not been vaccinated. Latest data disclosed by NHS England on 5 August show that patients aged 18-34 made up more than $20 \%$ of those admitted to hospital last month, up from close to one in 20, 5.4\%, at the peak of the winter wave in January.

“As young medics in our 20 s and 30s, we are very concerned to witness this happening to people our age. It all seems so unnecessary," the Scottish doctors wrote.

"The best way out of the pandemic and getting back to normal is through vaccination. The vaccines offer us all protection from covid-19, and lower the chance of passing the virus onto someone else."

The latest vaccination figures for England, for the week to $25 \mathrm{July}^{2}{ }^{2}$ show that more than $68 \%$ of 18 to 29 year olds have had a first dose, whereas it is $88 \%$ of all adults. Uptake varies by sex, with $70 \%$ of women aged 18 to 24 having had a first dose but only $62 \%$ of men. Among 25 to 29 years olds, $66 \%$ of men and $73 \%$ of women have had a first dose.

Miles Mack, chair of the Academy of Medical Royal Colleges and Faculties in Scotland, the umbrella group that represents Scotland's medical royal colleges, backed the trainees' action. "They want to show young people that there's nothing to fear by being vaccinated," he said. "In fact, being vaccinated gives peace of mind."

1 McLeod A, Elseedawy M, Cathcart J, et al. A letter from medics in their 20s and 30s. Academy of Medical Royal Colleges and Faculties in Scotland. Aug 2021. https://www.scottishacademy.org.uk/letter-medics-their-20sand-30s.

2 NHS England. Covid-19 vaccinations. https://www.england.nhs.uk/statistics/statistical-work-areas/covid-19-vaccinations.

This article is made freely available for use in accordance with BMJ's website terms and conditions for the duration of the covid-19 pandemic or until otherwise determined by BMJ. You may use, download and print the article for any lawful, non-commercial purpose (including text and data mining) provided that all copyright notices and trade marks are retained. 